\title{
On the development of a non-linear
} content estimation from the natural gamma ray $\log$

\section{Golnaz Jozanikohan* (1)}

\author{
*Correspondence: \\ gjkohan@ut.ac.ir \\ School of Mining \\ Engineering, College \\ of Engineering, Campus II, \\ University of Tehran, Junction \\ of Jalal-e-al-e-ahmad \\ and North Kargar St., P.O. \\ Box 14395-515, Tehran, Iran
}

\begin{abstract}
The Shurijeh Formation of Early Cretaceous age is an important clastic sandstone reservoir rock in the Gonbadli field, NE Iran. The quantitative determination of Shurijeh clay minerals has been considered to be a very important and challenging task due to the heterogeneity of formation. The calibrated gamma ray log has been traditionally used as the primary estimator of volume of clay in the subsurface formations. The comparison between the core-measured values and the resulting estimates from the old calibration methods in Shurijeh Formation revealed that despite of applying old calibrations, the Shurijeh clay contents suffers from overestimations. Thus, the most accurate calibration for natural gamma ray log was developed, using the integration of quantitative mineralogical analyses from 76 core samples to estimate the volume of clay in Shurijeh Formation. The least percent relative error, i.e., 11.4\%, was achieved in developing a new regression relationship in the form of a rational function acting as the most accurate non-linear clay indicator. The reliability of it was verified by the excellent correlation between the laboratory-measured clay contents in the core samples from another wells drilled in the mentioned Formation and the estimated values. The spectral log ratios have also been used to estimate the Formation depositional environment and different clay minerals types in it. It could truly be inferred that the Shurijeh was deposited in a marine environment with most of data having a thorium to uranium $(T h / U)$ ratio in the range of $1-10$. However, the indirect clay typing accomplished by several cross-plots, did not provide consistent results with the laboratorydetermined types from the XRD test.
\end{abstract}

Keywords: Clay mineral content estimation, Natural gamma ray log calibration, Shurijeh clastic reservoir formation, Core analysis

\section{Introduction}

The clay minerals are present in virtually all sandstone reservoirs, but the mineralogy, texture and distribution varies widely and affect both the production characteristics of the reservoirs and the wire-line log responses $[1,2]$. In terms of latter, a reliable estimation of clay content is the first and one of the most important steps in the quantitative formation evaluation studies [3-5]. If the volume of clay is overestimated, then the

(c) The Author(s) 2017. This article is distributed under the terms of the Creative Commons Attribution 4.0 International License (http://creativecommons.org/licenses/by/4.0/), which permits unrestricted use, distribution, and reproduction in any medium, provided you give appropriate credit to the original author(s) and the source, provide a link to the Creative Commons license, and indicate if changes were made. 
calculation of effective porosity, the effective water saturation $\left(\mathrm{Sw}_{\mathrm{e}}\right)$ will be too low, and this makes the reservoir to look productive. Similarly, if the volume of clay is underestimated, again the calculation of the effective porosity will be affected so that the effective water saturations $\left(\mathrm{Sw}_{\mathrm{e}}\right)$ will be overestimated and finally results in bypassing of a productive zone. Thus, in the worst case scenario, poor estimations of clay content can lead to overlooking of major hydrocarbon producers [6]. The volume of clay is also considered to be the basic information needed for the fault seal analysis [7]. Very small errors in prediction of the reservoir clay content or in its distribution pattern can lead to the large errors in estimations of fault permeability [8]. In the shale gas plays, the estimation of clay content is again important due to its controlling role on the frackability [9].

A key source of estimation errors stems from the incorrect interchangeable use of two terms "clay" and "shale" throughout the literature [8, 10-12]. Using the term "shale" instead of "clay" means that the shales are composed exclusively $100 \%$ of clay minerals with neither quartzitic silts nor the other detritus, which is not true [13-17]. If these two terms, i.e., the volume of shale and the volume of clay are used in place of another, the log derived values will deliver overestimations of the clay contents due to the fact that the petrophysical logs respond to the clay minerals contents rather than the shale contents (i.e., the grain size or the associated non-clay minerals) [12].

The clay minerals content can be obtained from various logs with certain advantages and inherent limitations, but the most commonly used technique and probably one of the most accurate methods is based on the using natural gamma ray log and the spectral components of it (i.e., $\mathrm{K}$, and $\mathrm{Th})[4,5,18]$. The natural gamma ray log and its spectral logging data, comprising potassium (wt\%), thorium (ppm), and uranium (ppm) respond to the natural radioactivity in the formation originates mainly from ${ }^{40} \mathrm{~K}(0.01167 \%$ of total naturally occurring potassium), ${ }^{232} \mathrm{Th}\left(100 \%\right.$ of natural thorium) and ${ }^{235} \mathrm{U}(99.27 \%$ of the total uranium) isotopes and their daughter products in the both cased and open boreholes [19]. The clay minerals are often the primarily radiation sources in the formations [11]. This means that the natural gamma ray and its spectral data are often capable of distinguishing between the clay-free (low reading) and the clay-rich sandstones (high reading) on general [20]. The response of the natural gamma ray log and its spectral components can be expressed as a linear function of the clay content (i.e., $\mathrm{I}_{\mathrm{A}}$ in Eq. 1) with assumption of the constant radioactivity, no additional radioactive elements, good borehole conditions, and no variation in the density [21].

$I_{A}=\frac{A_{\log }-A_{\min }}{A_{\max }-A_{\min }} \quad A=$ Gamma Ray (API), Potassium(\%) or Thorium (ppm)

where $I_{A}$ is the gamma ray/potassium/thorium index, $A_{\log }$ denotes the total natural gamma ray/potassium/thorium reading in the zone of interest, $A_{\min }$ shows the average natural gamma ray/potassium/thorium response of the clean (clay free) zone, $A_{\max }$ indicates the average natural gamma ray/potassium/thorium response of the pure clay zone [19].

However, some variations of the above-mentioned parameters can induce large effects on the $\log$ responses, so that the linear equation, called gamma ray index $\left(\mathrm{I}_{\mathrm{A}}\right.$ in Table 1 when A is the gamma ray log readings), gives an overestimate of the clay contents in the reservoirs. Thus, the linear gamma ray index should be modified using one of the 
Table 1 Calibration equations used to estimate the clay content from GR, K, and THOR logs

\begin{tabular}{lll}
\hline Larinov [22] & For highly consolidated and mesozoic rocks & $0.33\left(2^{\left.2 l_{A}^{*}-1\right)}\right.$ \\
& For unconsolidated tertiary clastics & $0.083\left(2^{\left.3.7 l_{A}^{*}-1\right)}\right.$ \\
Clavier [23] & $\begin{array}{l}\text { A good empirical compromise between the } \\
\text { tertiary and older rock equations }\end{array}$ & $1.7-\sqrt{3.38-\left(I_{A}^{*}+0.7\right)^{2}}$ \\
Steiber [24] & $\begin{array}{l}\text { Based on the different distribution of clay in } \\
\text { sandstones versus that in shales }\end{array}$ & $\frac{l_{A}^{*}}{3-\left.2\right|_{A} ^{*}}$ \\
Dewan [25] & $\begin{array}{c}\text { Based on the density differences between } \\
\text { clays in sandstones and clays in shales }\end{array}$ & $I_{A}^{*} \times\left(\frac{\rho_{b}}{\rho_{\text {sh }}}\right)^{3}$ \\
Bhuyan-Passey [10] & $\begin{array}{c}\text { Based on the weight percent clay of average } \\
\text { shale adjacent to the zone of interest }\end{array}$ & $C \times I_{A}^{*} ; 50<C<70(C$ is an empirical \\
& constant $)$
\end{tabular}

${ }^{*} I_{A}$ is the gamma ray/potassium/thorium index obtained from the standardization of natural gamma ray log and/or its components data. The $\rho_{\mathrm{b}}$ and $\rho_{\text {sh }}$ are the bulk density, and shale density, respectively

empirically derived non-linear calibration equations such as those introduced by Larinov [22], Clavier [23], Steiber [24], Dewan [25], or Bhuyan and Passey [10] (Table 1). These transforms are all in the non-linear form except for that of Bhuyan and Passey [10], which is developed based on the assumption that the estimation of weight percent clay can be modified by multiplying the gamma ray/potassium/thorium index by an empirical correction factor, i.e., C. This factor is basically determined from the weight percent clay content of average shale adjacent to the zone of interest [10], and commonly ranges from 50 to $70[10,13,14]$. Accordingly, the rock can be differentiated as clean, if the calculated clay content is less than $10 \%$; shaly sand if it ranged from 10 to $33 \%$ and if it is more than $33 \%$, it is considered to be shale [26].

The gamma ray activity in the formation is not solely related to the clay minerals. Therefore, even though the natural gamma ray logs are generally the best indicators of the clay content, they need to be used with caution $[10,11]$. The errors in the estimation of clay content from wireline logs can be reduced, if they are calibrated against the mineralogy data obtained from cores. Several studies produced good correlations between the laboratory-derived clay contents and the values determined from the modified natural gamma ray log and its spectral components data while the others did not support this fact. For example, Heslop [27] argued that the modified natural gamma ray log provide good correlations with the X-ray diffraction data. Johnson and Linke [28], based on the cation exchange capacity data within the Mackensie delta area, concluded that the modified natural gamma ray method does provide the reliable clay contents. Unlike, Causey [6] found out that the modified natural gamma ray log was the most accurate clay indicator in his study, though it did overestimate the clay contents when compared with the laboratory data. Jurado [29] confirmed that the modified natural gamma ray and its spectral components data are useful and effective tools in the identification/quantification of the clay minerals, because of their high and low readings in the shale and clean zones, respectively. Other various studies have been carried out using the integration of the laboratory, and the log-derived clay mineral values in the subsurface formations [18, 30-34].

The potassium and thorium concentrations are not only linked to the clay content, but also to the changes in the weathering regime of sediments in the source lands [35-37]. The thorium to uranium $(\mathrm{Th} / \mathrm{U})$ ratio varies with the sedimentary processes and products as well as with the depositional environment; therefore, it can be used to distinguish 
the environments and processes [38]. The $\mathrm{Th} / \mathrm{U}$ ratios in the sedimentary rocks range from less than 0.02 to more than 21 [38]. This ratio in the continental, oxidizing environment, weathered soils are above 7 , while the most marine deposits, gray and green shales, and graywackes have ratios that are $>2$ and $<7$. However, in marine black shales and phosphates, it reaches below 2 [18]. There are several studies in which the Th/U ratio was used to recognize the depositional environment [39, 40]. Schlumberger [41] has developed several cross-plots to estimate the clay mineralogy in the subsurface formations in the absence of laboratory data. Many authors used them to recognize different clay minerals types $[18,20,42,43]$.

In present study, the quantitative mineralogy from 76 core samples taken from the Shurijeh Formation is used to assess the accuracy of a multitude of existing modification methods on the natural gamma ray and its spectral components data. The accuracy of the procedures was checked on the basis of minimum average percent relative error of each petrophysical method for estimation the volume of clay, using the comparison of the log-derived values with the true laboratory-measured volume percent of clay minerals. Some attempts have also been made to calibrate the logging values with the laboratory-derived clay contents of 76 core samples by running a non-linear regression calibration relationship between the core-measured clay contents and the natural gamma ray index. Finally, the depositional environment and different clay types of the Shurijeh Formation were recognized, using the spectral gamma ray logging ratios and the relevant cross-plots, respectively.

\section{The geological setting}

The data used in this research were all collected from a gas producing well and another non-producing deep vertical well drilled in the Gonbadli gas field, Eastern Kopet-Dagh sedimentary Basin, NE Iran. The subject basin is one of the Iranian tectono-sedimentary units extending from the east of Caspian Sea to the NE Iran (Fig. 1). It is believed that it has been formed in an extensional regime after the closure of Paleo-Tethys in the Middle Triassic [44] and the opening of Neo-Tethys during the Early to Middle Jurassic [45]. The sedimentation went on relatively uninterruptedly in this basin from Jurassic through Miocene with over $6000 \mathrm{~m}$ of section in Sarakhs area [46]. The carbonates of JurassicCenozoic and siliciclastics unconformably overlie Palaeozoic (the basement) and Triassic rocks in this region [47].

Discovered in 1969, the Gonbadli gas field was drilled on the elongated symmetrical Gonbadli structure (Fig. 1) with a production capacity of $1.1 \mathrm{mcm} /$ day [48]. The reservoir rock of the Gonbadli field is the Shurijeh Formation (aged Neocomian). This formation is primarily composed of mixed red bed siliciclastic sediments, mostly fine to medium grained rocks (shales, siltstone and sandstones) with the carbonates and evaporates lithofacies. These were deposited in a variety of continental (fluvial, ephemeral lake depositional systems), coastal, and marine environments through Late Jurassic-Early Cretaceous times [49]. The thickness of the Shurijeh Formation in the Gonbadli wells varies from 174.5 to $259.1 \mathrm{~m}$ and approximately starts somewhere in the $3 \mathrm{~km}$ below rotary tables [48]. The Shurijeh has been divided into three parts of upper, middle and lower, based on its varying mineralogy with five lithological units as lithofacies A, B, C (subdivided into $\mathrm{C}_{1}$ and $\mathrm{C}_{2}$ units), $\mathrm{D}$ (subdivided into $\mathrm{D}_{1}$ and $\mathrm{D}_{2}$ units) and $\mathrm{E}$ (Table 2) 


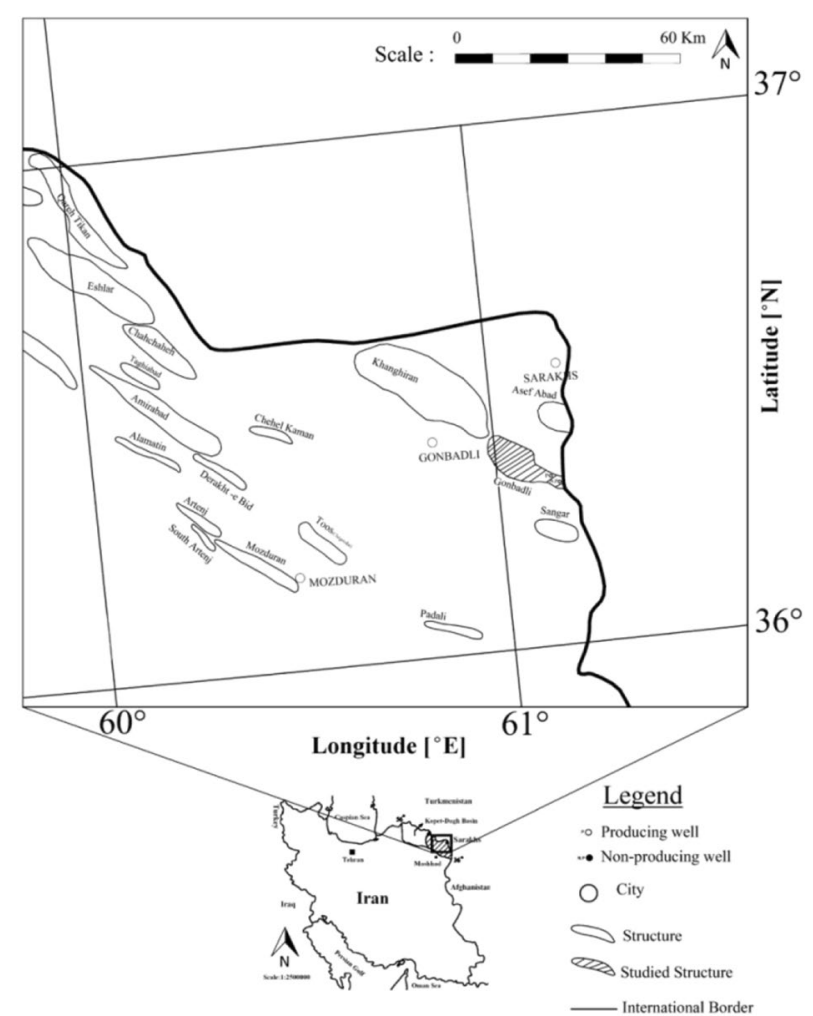

Fig. 1 The geographic location map of the studied area, modified from [50]

in which the sand rich unit $\mathrm{D}_{1}$ is characterized as the main gas bearing horizon in the studied area [48]. Four of the main points of difference between $D_{1}$ and $D_{2}$ units; $C_{1}$ and $\mathrm{C}_{2}$ units, are summarized in the degree of cementation, the type of formation fluids, the amount of porosity and matrix [48]. The thickness of reservoir unit, $\mathrm{D}_{1}$, in the Gonbadli field varies between 24.5 and $40.66 \mathrm{~m}$ [48].

\section{Materials and methods}

\section{Materials}

\section{Core samples}

Out of the 76 core samples taken almost every half meter of the Shurijeh Formation, 20 samples were located between depths of 3202.8 to $3210 \mathrm{~m}$ in a gas producing well and the remaining 56 samples located between depths of 3180 to $3207.55 \mathrm{~m}$ in another nonproducing well. The outer parts of each core sample were carefully removed to prevent from any possible contaminations or oxidation effects. The samples were then crushed $(<\mathrm{mm})$ and thoroughly mixed to obtain a homogeneous mixture.

\section{Wireline logging data}

In the absence of elemental capture spectroscopy (ECS) log, a set of conventional logging measurements, including the photoelectric effect (PEF), gamma ray and the natural radioactivity by separating $\mathrm{K}, \mathrm{Th}$, and $\mathrm{U}$ contents, was used in this study. The vertical sampling interval of $15 \mathrm{~cm}$ provided 712 data samples in the Shurijeh Formation from 


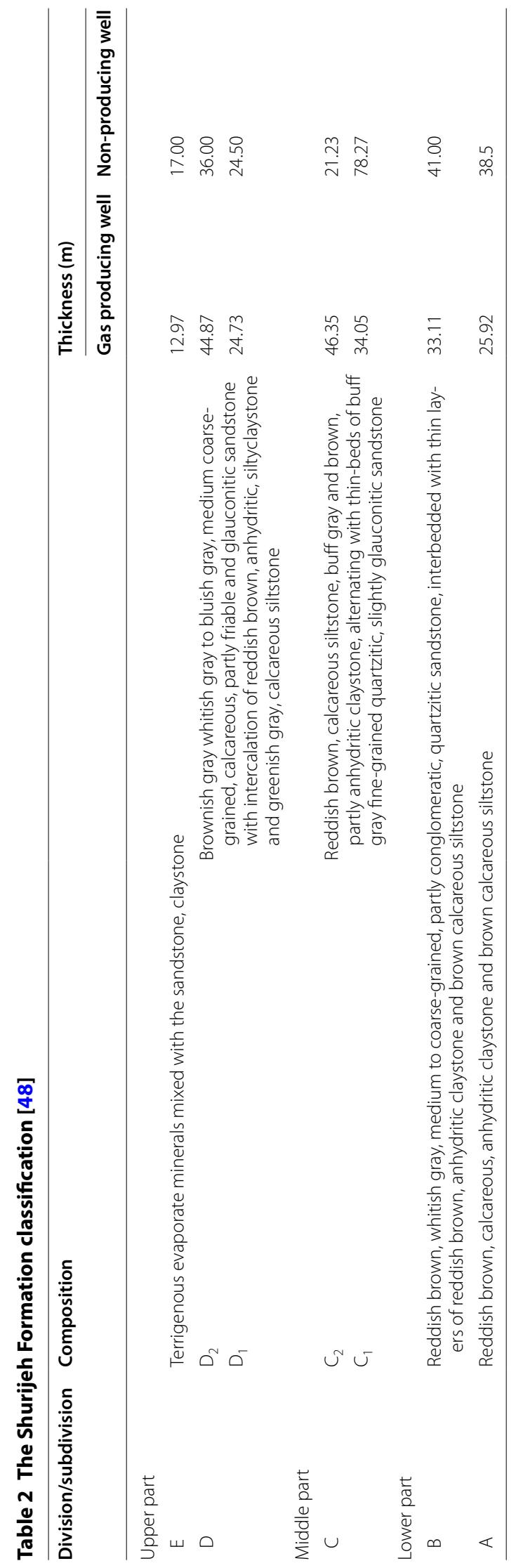


the depth of $3182.9 \mathrm{~m}$ down to $3254 \mathrm{~m}$ in the gas producing well. The same vertical sampling interval provided 458 data from the depth of $3174 \mathrm{~m}$ down to $3219.7 \mathrm{~m}$ in the non-producing well. To overcome the possible signal attenuation due to the variations in the borehole and mud weight [19], Schlumberger [41] environmental correction chart, GR-1, was used to correct the natural gamma ray and its spectral components data. The drilling mud in the both wells was checked for existence of any possible amounts of radioactive minerals such as $\mathrm{KCl}$ and no evidence of them were found. In most cases, the locations of 76 mineralogical data were not at the same depth as the logging data. Therefore, the average of two nearest log measurements was calculated for a given mineralogical data. Some core samples from another wells drilled in the mentioned formation were also chosen and set apart to validate the accuracy of the empirical non-linear relationship found later for the purpose of clay content estimation in the Shurijeh Formation.

\section{Methods}

\section{The quantitative XRD mineralogical analyses}

The X-ray diffraction (XRD) is the most widely used method of clay minerals identification/quantification [51] and it was used to both identify and quantify bulk and clay mineralogy of the Shurijeh Formation. All of the crushed core samples were exposed to $\mathrm{Ni}$-filtered $\mathrm{Cu} \mathrm{K} \mathrm{K}_{\alpha}$ radiation generated by a Bruker AXS, D8 Advance X-ray diffractometer and were scanned from 4 to 70 degrees for bulk mineralogy and 4-40 degrees for the clay mineralogy, both at a speed of $1.2^{\circ} 2 \theta / \mathrm{min}$ at $40 \mathrm{kV}$ and $30 \mathrm{~mA}$.

\section{Results}

The X-ray diffraction (XRD) analysis

The whole-rock powder diffractometry results indicate that the main constituents of the samples are quartz, and plagioclase, while the secondary minerals are clays, anhydrite, carbonates (dolomite and calcite), K-feldspar, and hematite. The clay extraction procedures [51] were performed to prepare the oriented slides from the less than four micron size fraction. The XRD patterns of the air-dried, glycolated, heated and treated with the hydrochloric acid were carefully studied to identify the clay minerals type. It was concluded the clay minerals consisted mainly of illite, magnesium rich chlorite, kaolinite with smaller amounts of glauconite, montmorillonite and mixed layer clays such as illite/ montmorillonite and montmorillonite/chlorite types. The percentages of each individual clay mineral were then determined by comparing the intensities of standard samples to the core samples as a ratio, using the standard calibration curves. All the standards were pretreated according to the same procedures as the core samples to separate as well as orientation of less than four micron size fraction. The clay content of each sample was then defined as the sum of all different types of clay minerals respective mean concentrations. A system of simultaneous linear equations formulated successfully checked the accuracy of XRD mineral percentage estimates on the basis of detailed elemental information of the core samples from the XRF analysis [52]. Detailed quantitative XRD analysis yielded the average clay contents which vary from 9.2 weight percent in the gas producing well to 13.3 weight percent in the non-producing well. The average bulk and clay mineralogy of the Shurijeh Formation is shown in Figs. 2 and 3, respectively. It is clear that each well contains large amounts of illite and low concentrations of 


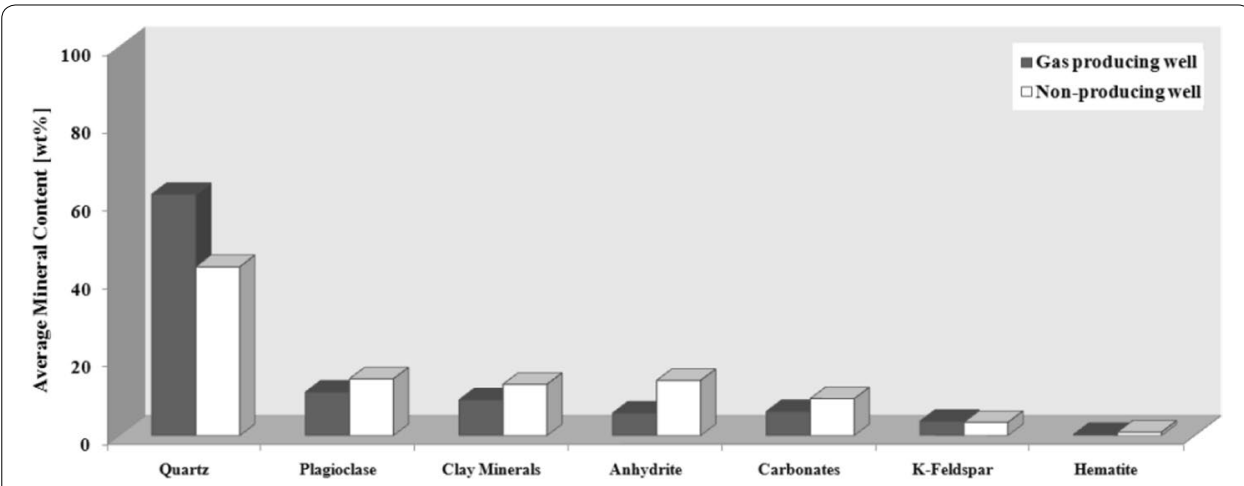

Fig. 2 The quantitative mineralogical data of the Shurijeh Formation from the XRD analysis

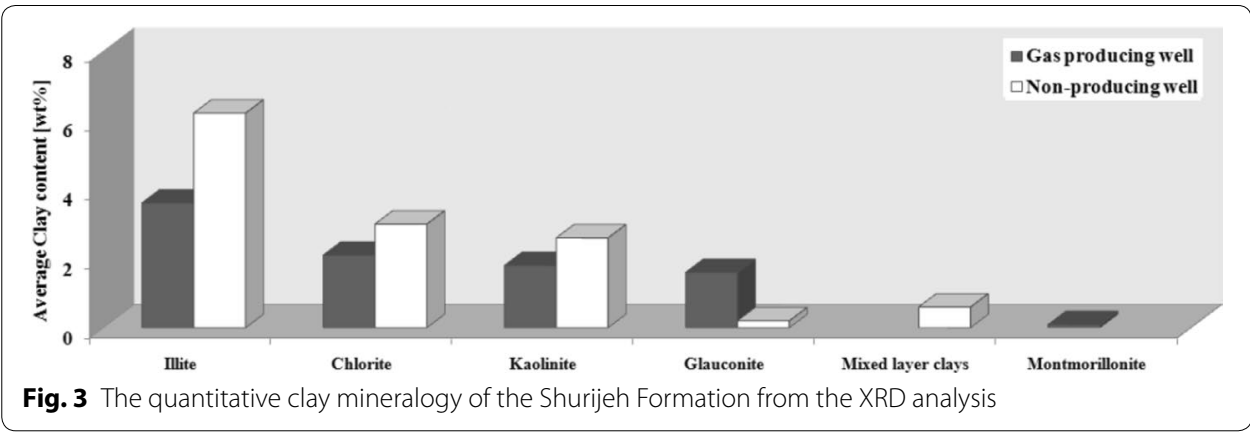

non-radioactive clay minerals such as kaolinite, which makes the natural gamma ray log and its components data, suitable for indirect estimations of the clay contents.

\section{The weight percent clay estimation from the natural gamma ray log}

Generally, the uranium is not associated with the clay minerals and it is more indicative of the natural fractures or the organic matter content or the redox conditions experienced by the formation particularly soon after burial $[11,33]$. Thus, it was not used for the clay content estimation purpose in the present study. Since the natural gamma ray $\log$ and its spectral components counts are proportional to the weight percent clay and not to the volume percent clay [10], no conversion of weight percent XRD data to the volume percent was performed. After depth matching (described in "Wireline logging data" section), the existence of a linear relationship between weight percent clay from the XRD data, the natural gamma ray log and its spectral components, including potassium and thorium values were checked by computing the Pearson's correlation coefficient in Matlab 7.11.0 software (Table 3). For comparative visualization of data, the clay contents in the core samples, as well as the relevant gamma ray, potassium, and thorium values as a function of depth in both wells are shown in Fig. 4.

The linear natural gamma ray and the potassium and thorium indexes $\left(\mathrm{I}_{\mathrm{GR}}, \mathrm{I}_{\mathrm{POTA}}\right.$, and $\left.\mathrm{I}_{\mathrm{THOR}}\right)$ were continuously calculated at each depth level from the corrected logging data, using the Eq. (1).

Table 4 summarizes the pertinent well data used for calculation of the gamma ray, potassium, and the thorium indexes. Their comparison with the actual measured clay 
Table 3 The Pearson's correlation coefficient between log values and the core-measured clay contents

\begin{tabular}{|c|c|c|c|c|c|c|c|c|}
\hline & Gas produ & cing well & & & Non-prod & lcing well & & \\
\hline & GR (GAPI) & $\begin{array}{l}\text { Potas- } \\
\text { sium (\%) }\end{array}$ & $\begin{array}{l}\text { Thorium } \\
\text { (ppm) }\end{array}$ & $\begin{array}{l}\text { Core- } \\
\text { measured } \\
\text { clay } \\
\text { minerals } \\
\text { contents } \\
(\%)\end{array}$ & GR (GAPI) & $\begin{array}{l}\text { Potas- } \\
\text { sium (\%) }\end{array}$ & $\begin{array}{l}\text { Thorium } \\
\text { (ppm) }\end{array}$ & $\begin{array}{l}\text { Core- } \\
\text { measured } \\
\text { clay } \\
\text { minerals } \\
\text { contents } \\
(\%)\end{array}$ \\
\hline GR (GAPI) & 1 & & & & 1 & & & \\
\hline $\begin{array}{l}\text { Potassium } \\
\text { (\%) }\end{array}$ & 0.174 & 1 & & & 0.908 & 1 & & \\
\hline $\begin{array}{l}\text { Thorium } \\
\text { (ppm) }\end{array}$ & 0.442 & 0.776 & 1 & & 0.879 & 0.835 & 1 & \\
\hline $\begin{array}{l}\text { Core- } \\
\text { meas- } \\
\text { ured clay } \\
\text { minerals } \\
\text { contents } \\
(\%)\end{array}$ & 0.898 & 0.315 & 0.624 & 1 & 0.446 & 0.385 & 0.287 & 1 \\
\hline
\end{tabular}

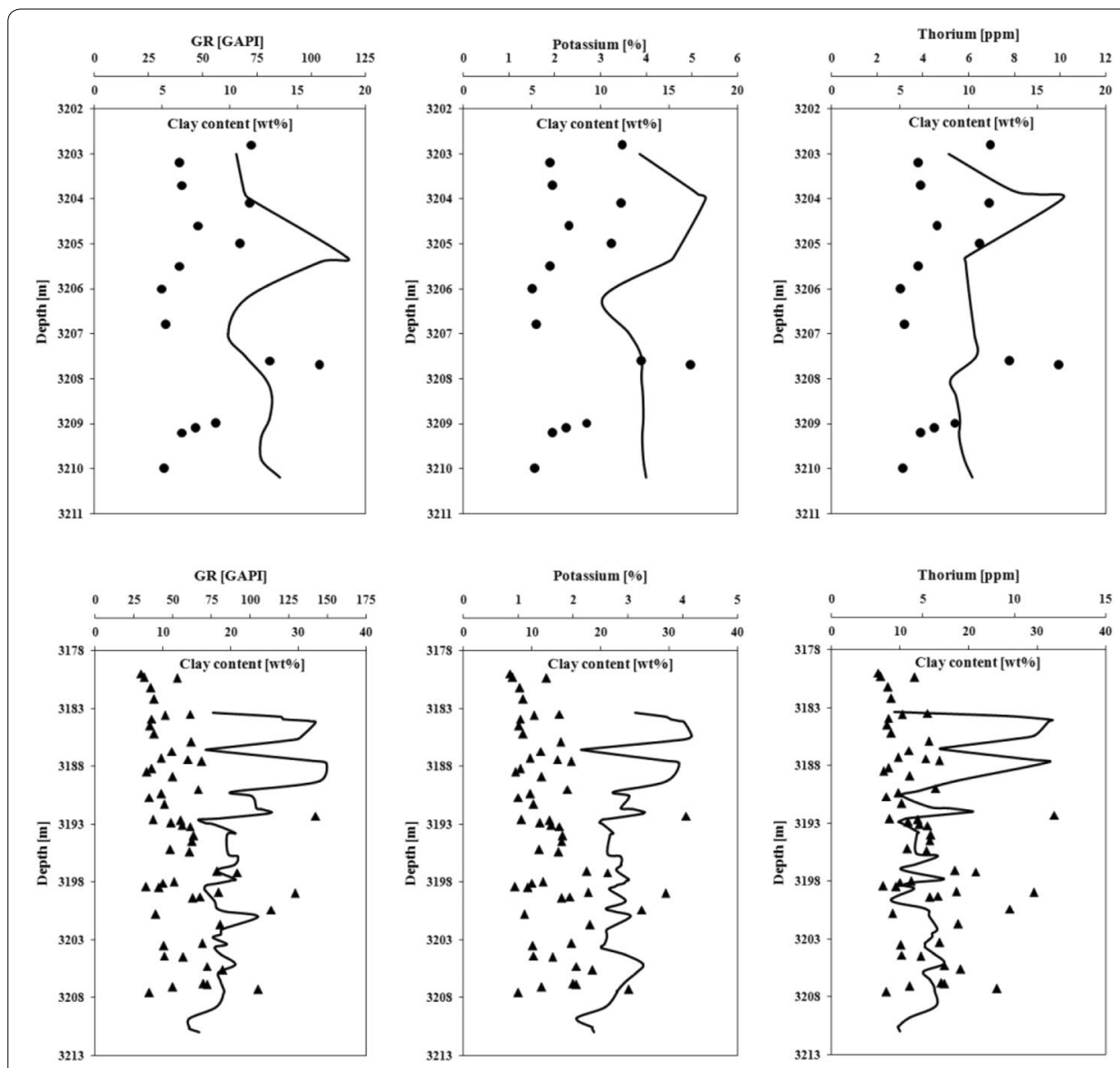

Fig. 4 The Shurijeh GR, K, THOR data vs core-measured clay minerals contents as a function of depth. Black circle Gas producing well data points, black up-pointing triangle non-producing well data points 
Table 4 The summary of minimum and maximum values of the log readings in the Shurijeh Formation

\begin{tabular}{lcc}
\hline Log & Minimum & Maximum \\
\hline GR (GAPI) & 22.2 & 247.7 \\
Potassium (\%) & 0.455 & 9.38 \\
Thorium (ppm) & 1.14 & 28.3 \\
\hline
\end{tabular}

content from the XRD analysis (Fig. 5) showed that the unmodified gamma ray, potassium, thorium indexes calculated from the linear Eq. (1) provided wide overestimation of the Shurijeh clay content, which leads eventually to the misestimating of the original hydrocarbon in place and reserves. Thus, the values of linear gamma ray, potassium, and thorium indexes were modified, using each of the empirically derived non-linear transform equations introduced by Larinov [22], Clavier [23], Steiber [24], Dewan [25], or Bhuyan and Passey [10] (all the relationships are listed in Table 1) to obtain a less erroneous estimation of Shurijeh clay content. According to the Shurijeh age (Early Cretaceous), Larinov calibration for highly consolidated formations was used and based on the data in Fig. 6, $\rho_{s h}$ in Dewan equation which is corresponding to the highest gamma ray reading considered to be $2.75 \mathrm{~g} / \mathrm{cc}$ units. The $\mathrm{C}$ factor in the Bhuyan-Passey modification was considered to be 60 for the Shurijeh Formation after measuring the clay contents of reference adjacent shale in many surface samples. The estimated clay content from modified gamma ray, potassium, and thorium indexes are given in Table 5.

Since the errors associated with the previous modifications made a comparatively large difference to the results, it is important to derive an empirical relationship for the clay content estimations in this formation. Attempting to calibrate the core to log data, a simple non-linear regression relationship was run in Matlab 7.11.0 software. Shown below is the obtained non-linear calibration relationship for the Shurijeh Formation in the form of a rational function between natural gamma ray index as independent variable and the

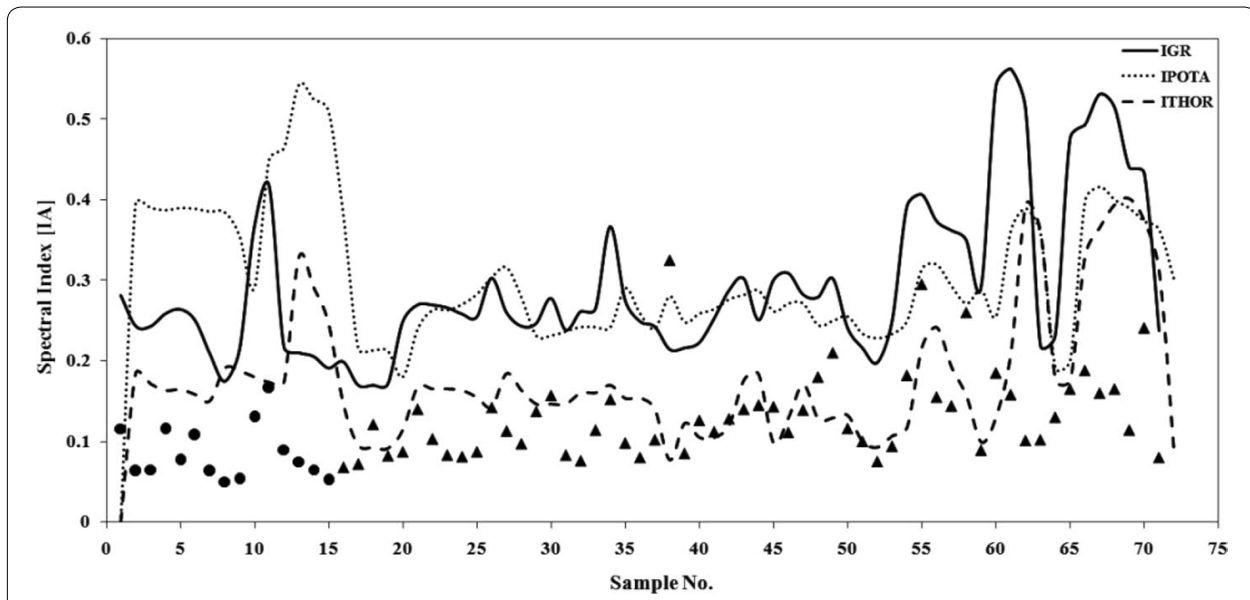

Fig. 5 The comparison between unmodified ray indexes and core-measured clay contents. Black circle Gas producing well data points, black up-pointing triangle non-producing well data points 


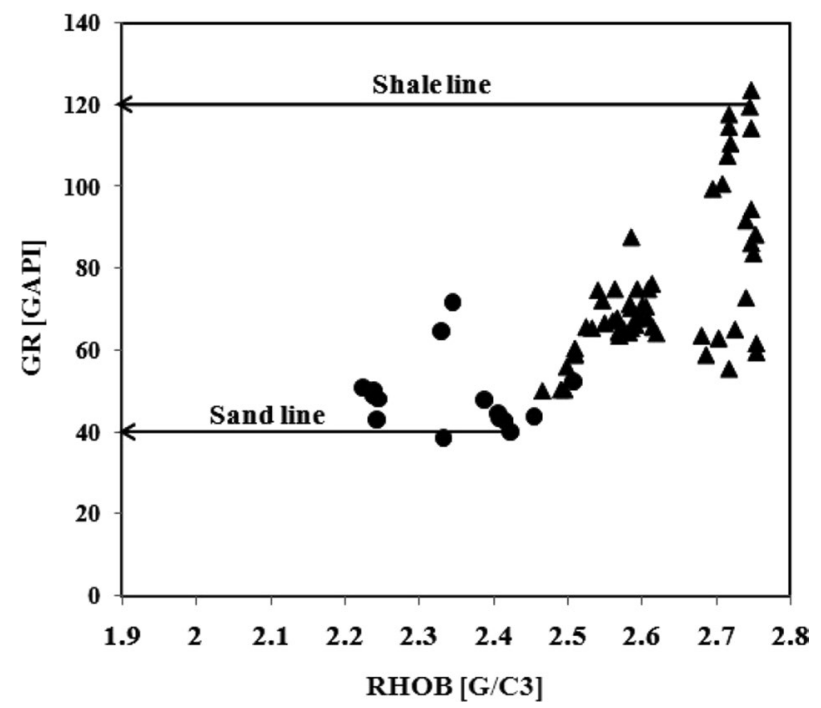

Fig. 6 Density vs GR in the core samples of the Shurijeh Formation. Black circle Gas producing well data points, and black up-pointing triangle non producing well data points

Table 5 The average weight percent clay contents from the modified GR, K, and THOR indexes

\begin{tabular}{|c|c|c|c|c|c|c|c|c|c|c|c|c|}
\hline & \multicolumn{2}{|c|}{ Larinov } & \multicolumn{2}{|c|}{ Clavier et al. } & \multicolumn{2}{|c|}{ Steiber } & \multicolumn{2}{|c|}{ Dewan } & \multicolumn{2}{|c|}{$\begin{array}{l}\text { Bhuyan- } \\
\text { Passey }\end{array}$} & \multicolumn{2}{|c|}{$\begin{array}{l}\text { Empirical } \\
\text { relationship }\end{array}$} \\
\hline & GP & NP & GP & NP & GP & NP & GP & NP & GP & NP & GP & NP \\
\hline GR & 13.85 & 17.80 & 12.77 & 16.47 & 10.16 & 13.20 & 15.54 & 27.14 & 15.00 & 18.23 & 9.88 & 11.45 \\
\hline K & 25.99 & 15.61 & 24.13 & 14.41 & 19.45 & 11.47 & 26.03 & 24.49 & 24.95 & 16.63 & 14.62 & 10.66 \\
\hline Th & 10.32 & 9.38 & 9.48 & 8.62 & 7.54 & 6.87 & 12.27 & 15.69 & 11.66 & 10.50 & 8.25 & 7.53 \\
\hline
\end{tabular}

GP gas producing well, NP non-producing well

laboratory-derived weight percent clay based on the X-ray diffraction analysis as the dependent variable:

$$
\text { Weight Percent Clay }=\frac{0.69 I_{G R}}{1+3.9 I_{G R}-3.75 I_{G R}^{2}}
$$

The natural gamma ray index was chosen for running the regression analysis due to the stronger correlation coefficient in compare to the potassium or thorium indexes, with the core clay contents in both wells. The unique feature of new equation is to calculate the clay content of less than $100 \%$ with a given $\mathrm{I}_{\mathrm{GR}}$ of 1.0 , while all other previous modifications give clay content of $100 \%$ for such $\mathrm{I}_{\mathrm{GR}}$ value. The assumption used in developing the non-linear relationships was based on the fact that the entire radioactivity is not due to the clay minerals only. The goodness of agreement and the reliability of the regression equation were then both verified by a correlation coefficient of 0.992 upon application on some other core samples from another wells drilled in the Shurijeh Formation. It is clear from the data in Fig. 7 that the core data, verify both the very low and the medium range of clay contents, estimated from the non-linear empirical relationship. The average 


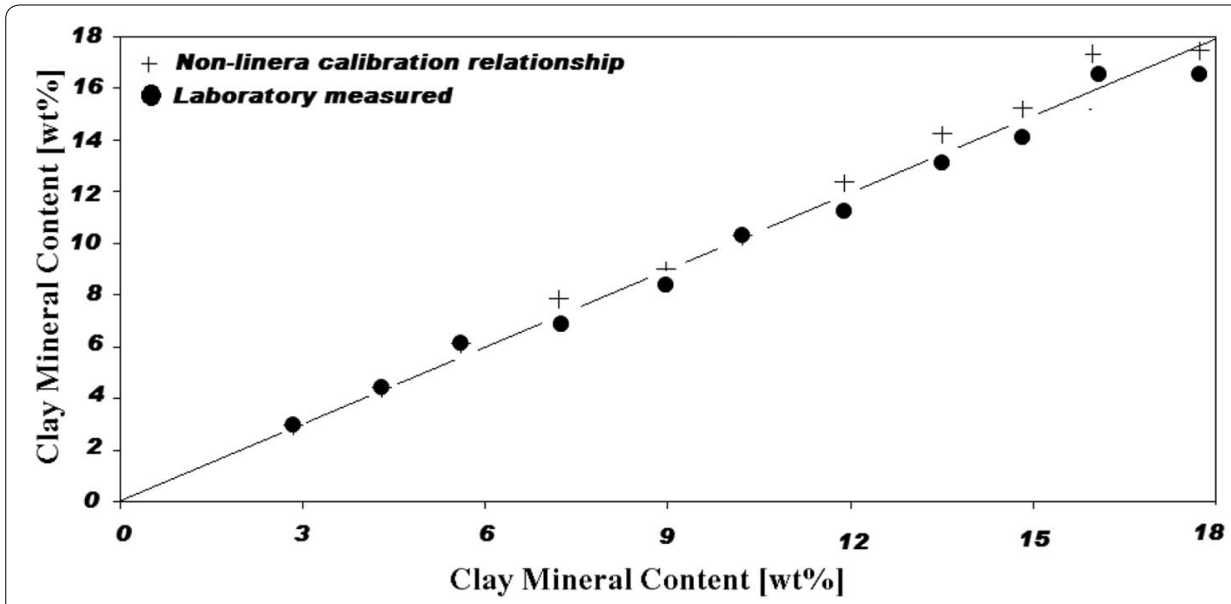

Fig. 7 The comparison between the core-measured clay contents and the estimated values from the empirical non-linear calibration relationship

percent relative error was also minimized to $11.4 \%$. Due to the statistical bias of comparing data samples with very different sizes and variances (76 samples versus 11 samples), the error cannot be reduced further. Figure 8 shows the relationship of weight percent clay from the XRD measurements of both wells and modified natural gamma ray index using different equations including highly consolidated Larionov transform, Clavier et al., Steiber, Dewan, Bhuyan-Passey and the empirical transforms. The clay content was also estimated from the potassium and thorium indexes using the empirical nonlinear calibration (Table 5) and a comparison of average percent relative errors for different equations has been shown in Fig. 9.

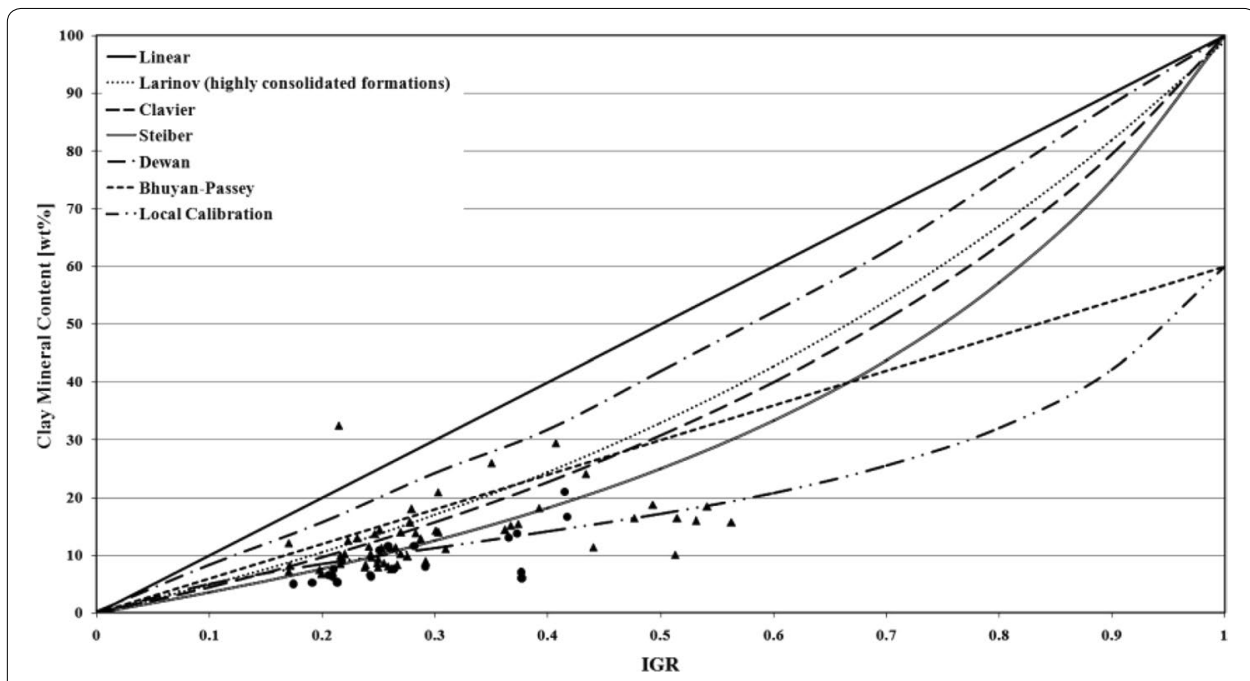

Fig. 8 The comparative look at the Shrijeh Formation weight percent clay from the core analysis and different modifications proposed by Larinov [22], Clavier [23], Steiber [24], Dewan [25], Bhuyan and Passey [10] and the empirical calibration relationship (dashed curvilinear lines). Black circle Gas producing well data points, and black up-pointing triangle the non-producing well data points 


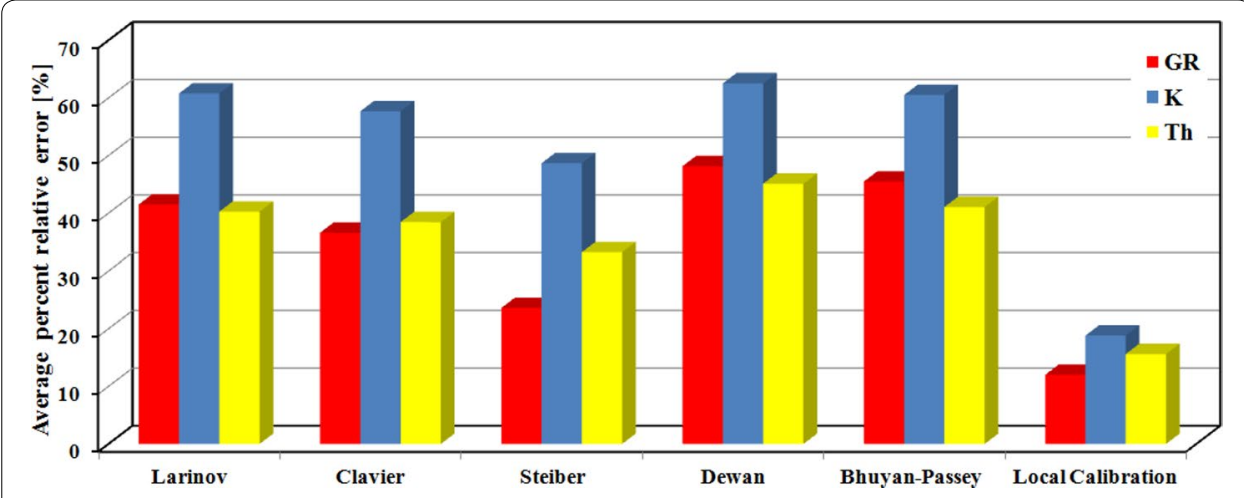

Fig. 9 The average percent relative errors of different modifications of the GR, K, and THOR indexes

The depositional environment and the clay typing based on the spectral gamma ray ratios

$\mathrm{Th} / \mathrm{U}$ ratio cross-plot was generated for the cored intervals of each well to investigate on the depositional environment (Fig. 10).

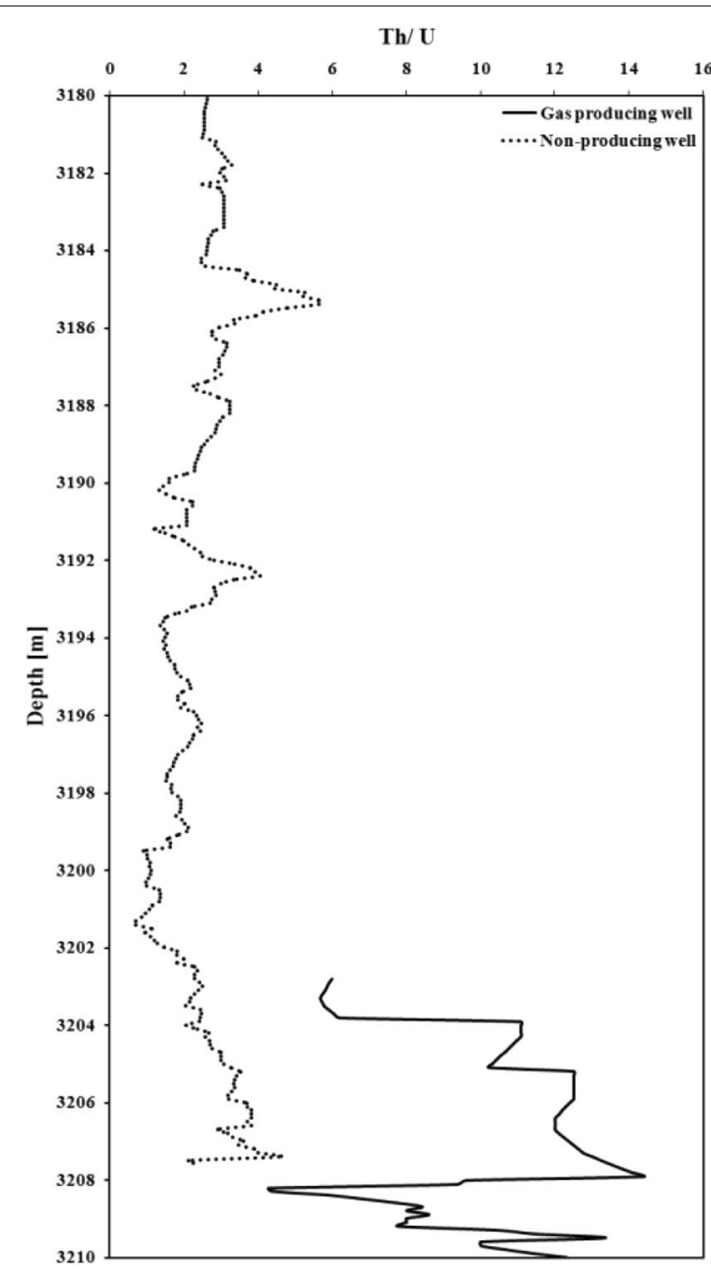

Fig. $10 \mathrm{Th} / \mathrm{U}$ ratio in the Shurijeh reservoir Formation 
The clay typing was later accomplished by a group of cross-plots (Fig. 11) with various combinations including thorium versus potassium, photoelectric (PEF) versus potassium, photoelectric versus $\mathrm{Th} / \mathrm{K}$ ratio and thorium versus $\mathrm{Al}_{2} \mathrm{O}_{3} /\left(\mathrm{Al}_{2} \mathrm{O}_{3}+\mathrm{SiO}_{2}\right)$. For generating the last one [40], the XRF data were used. The presence of clay minerals like illite, montmorillonite and glauconite are evident from Fig. 11, however chlorite and kaolinte are not detected by this method.

\section{Discussion}

Due to the insignificant contribution of the potassium-free clay minerals in the Shurijeh Formation, the natural gamma ray, potassium and thorium logging data were used confidently to obtain estimates of Shurijeh clay content. There was a strong linear correlation between the weight percent clay and the natural gamma ray log data based on the Pearson's correlation coefficient. According to the XRD results, the non-producing well was more shaly with a clay quantity of one and a half order of magnitude larger than that was in the gas producing well. The clay content calculated from the modified natural gamma ray log and its spectral components data, exceeded the actual core-measured of this parameter, probably because of the other non-clay radioactive minerals and/or the size of sampling. It is clear that the borehole logging instrument measures the natural radioactivity in a large portion of rock weighing many kilograms, in contrast to the core sample which represents only a small portion of a kilogram. This is known as the size sampling effect. On the density versus gamma ray cross-plot (Fig. 6), most of data points of non-producing well, which exhibited a high amount of gamma ray activity, plotted toward the up right corner of the cross plot, while the gas producing well data points
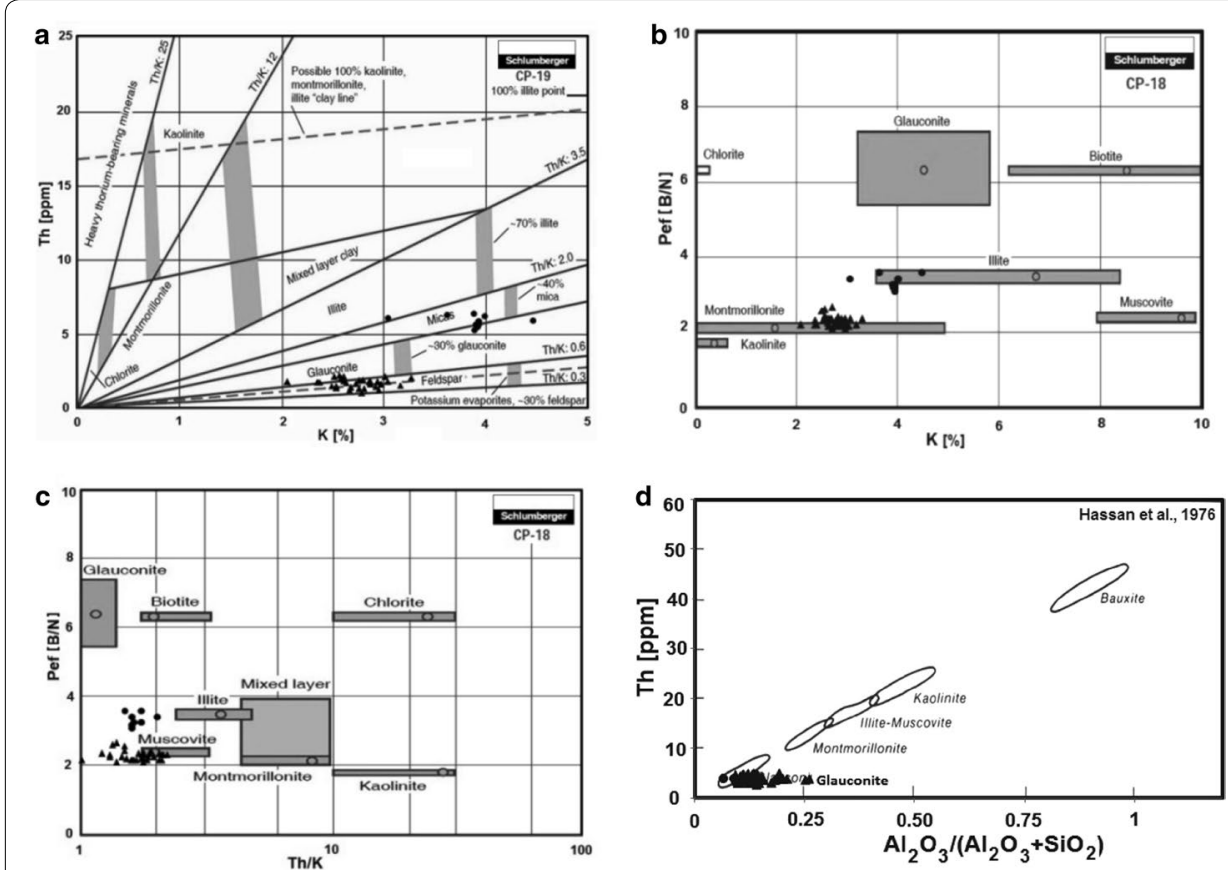

Fig. 11 The results of log-derived clay typing: a Th (vs) K, from Schlumberger [41]; b PEF (vs) K, from Schlumberger [41]; c PEF (vs) Th/K, from Schlumberger [41]; d Th (vs) $\mathrm{Al}_{2} \mathrm{O}_{3} /\left(\mathrm{Al}_{2} \mathrm{O}_{3}+\mathrm{SiO}_{2}\right)$ from [40]. Black circle Gas producing well data points, and black up-pointing triangle non-producing well data points 
fell toward the left corner of the cross-plot (showing lower densities and radioactivities). It was investigated from Fig. 9 that the two most precise estimator logs for the clay content estimations in the Shurijeh Formation were the gamma ray and thorium logs, whereas the potassium log had the most estimation errors due to the existence of potassium deficient clays such as kaolinite and chlorite. On the basis of the average percent relative error, among all of the previously proposed modifications in the Shurijeh Formation, those introduced by Dewan, Bhuyan-Passey, and Larinov had the most widely overestimations. Dewan equation produced the largest estimation errors, because of the exponential value of 3 in its formulation, which was an educated guess and there was no measured data in the literature to support it. Buhyan-Passey modification generated relatively erroneous estimations, due to the non-realistic assumption of identical properties for both clay minerals in the clastic reservoirs and the adjacent shales. Larinov equation for the highly consolidated rocks provided overestimations as well and the reason for this inapplicability might lie in the general assumption used in its formulation. It is being formulated based on the fact that the older rocks subjected to deep burial contain more illitic minerals than the other rocks due to the illitization of smectite as a function of burial depth. Since there are many exceptions to this generalization, if clay contents are picked from Larinov older rock curve, like what is shown in Fig. 8, they are subject to an error. The modification proposed by Clavier [23] was a good compromise between the tertiary and older rock equations for estimation of the clay contents in the reservoirs; however, it appeared to slightly overestimate the clay content of the Shurijeh reservoir Formation (Fig. 8). The agreement between the XRD data and the Stieber estimates was satisfactory; nevertheless the estimations given by the empirical calibration improved the accuracy of the estimations much better than that. For the clay content estimation purpose, the application of the empirical relationship was found more reliable than the previously proposed modifications of the natural gamma ray log, due to its indicator values and low estimation errors. The estimation errors of all of the previously proposed modifications were depended to the log type (the gamma ray, potassium or thorium $\operatorname{logs}$ ), unlike the empirical non-linear calibration which had approximately equal errors for all of the different types of logs. Overall, it seemed that the generalization ability of the empirical non-linear calibration relationship was much better than the previous calibrations and the fitting error of the model was less. The average clay contents achieved by the locally calibrated gamma ray index were 9.88 and $11.45 \%$ in the gas producing and non-producing well, respectively. These amounts were much lower than the values obtained from the former modifications and were in more accordance with the laboratory measured data. These findings have had a great impact on the estimation of hydrocarbon in place and reserves of the Shurijeh. Overall, both the actual and estimates of weight percent clay from the different modifications, placed the Shurijeh Formation in the shaly sandstone category.

It can also be inferred from this study that, the Shurijeh reservoir Formation was deposited in the marine environment as Th/U ratio varied between 1.8 and 23.2 in the gas producing well and between 1.2 and 5.6 in the non-producing well. Most of the data points in both wells read $\mathrm{Th} / \mathrm{U}$ ratios less than 10 indicating that, the depositional environment had a marine nature. The higher $\mathrm{Th} / \mathrm{U}$ ratio in the gas producing well might be due to more oxidizing conditions or to a higher concentration of other radioactive 
minerals such as K-feldspar or heavy minerals in the sand size fraction. The intermediate $\mathrm{Th} / \mathrm{U}$ ratio about 2-7 in the non-producing well showed a low grade of weathering and leaching of uranium, or it can be inferred as a sign of mixtures of materials from low and high ratio environments. The finding was in agreement with cored intervals of the Shurijeh depositional environment described by Moussavi-Harami and Brenner [49].

The cross-plots investigations made it clear that the Shurijeh is not a clean reservoir because distinct cluster data points were not close to the origin in none of the crossplots shown in the Fig. 11; they were all clustered in the lower left-hand corner of each cross plot. Less differences within wells rather than between wells, suggested some systematic changes such as different diagentic histories between wells. The data points of the gas producing well were less well discriminated but all showed relatively moderate potassium and thorium on cross plot marked A from Fig. 11. For both wells, the data points on the clay typing cross-plots fell in a particular area that showed the general types of the clay minerals in the area. However, some data from both wells were shifted away from the trend. Although, there was no agreement on the clay types introduced by each cross-plot, but based on the results provided from all of them, the clay mineralogy in the formation under study could be concluded as only of glauconite/smectite/ muscovite/Illite types. These results were not in agreement with that of the XRD laboratory studies carried out on the core samples of both wells. The kaolinite, chlorite, and the mixed layer clay minerals were also remained unrecognized by this petrophysical technique.

\section{Conclusions}

In this paper, all previously proposed modifications of natural gamma ray log and its spectral components data were reviewed and a new calibration equation for reliable assessment of the clay content in the Shurijeh reservoir Formation was presented. The quantitative $\mathrm{XRD}$ results showed a low average percentage of clay minerals for the gas producing well and moderate amounts for the non-producing well. The differences between the varying amounts of clay minerals in wells were attributed to the changes in the diagentic histories. In both wells, all the previously proposed modifications overestimated the weight percent clay indicating it is critical to calibrate petrophysically-derived weight percent clay to the laboratory data to find better estimations. The results also showed by using natural Steiber modified gamma ray values, more reliable clay contents could be obtained rather than all other previous modifications in this area. On the basis of minimum average percent relative error, the natural gamma ray and thorium curves were powerful tools to recognize the clay zones in a sandstone reservoir rather than potassium curve. In summary, the comparison of core clay contents from quantitative XRD data, estimated values using the previously proposed modifications and the empirical calibration, demonstrates that a simple nonlinear regression using the XRD data and natural gamma ray index $\left(\mathrm{I}_{\mathrm{GR}}\right)$ allows for the quantification of clay content with the least percent relative errors, i.e., lower than $12 \%$, which is comparable to the values of the methodological errors associated with the XRD analysis. This empirical relationship was the most efficient estimator for up to $20 \%$ weight percent clay content; the most common situation in the sandstone reservoirs. The excellent agreement between the locally calibrated natural gamma ray index and the clay quantitative XRD data showed it was 
well suited to provide reliable quantitative clay content estimates. The application of the proposed approach in this paper, will significantly improve the weight percent clay estimations from the gamma ray log in the Gonbadli field. The depositional environment can be correctly recognized from the spectral gamma ray logging ratio, however the safest method of reservoir clay typing is still based on the laboratory analysis of core samples. Overall, the natural gamma ray log and its spectral components data proved to be dependable qualitative and quantitative tools to diagnose clay minerals in sub-surface formation studies. In this paper, the broad scope of problem-solving capability of them was illustrated in the reservoir formation evaluation.

Acknowledgements

The acknowledgements are due to the University of Tehran and National Iranian Oil Company, Exploration Directorate for providing data as well as their technical and financial support during the research work.

Competing interests

The author declares that she has no competing interests.

Ethics approval and consent to participate

Not applicable.

Funding

This research did not receive any specific grant from any funding agencies in the public, commercial, or not-for-profit sectors.

\section{Publisher's Note}

Springer Nature remains neutral with regard to jurisdictional claims in published maps and institutional affiliations.

Received: 13 June 2017 Accepted: 25 October 2017

Published online: 01 November 2017

\section{References}

1. Hurst A (1987) Mineralogical analysis and the evaluation of the petrophysical parameter Vshale for reservoir description. Mar Pet Geol 4(1):82-91

2. Barson D, Christensen R, Decoster E, Grau J, Herron M, Herron S, Guru UK, Jordán M, Maher TM, Rylander E, White J (2005) Spectroscopy: the key to rapid, reliable petrophysical answers. Oilfield Rev. 17(2):14-33

3. Soto Becerra R, Arteaga D, Hidalgo CM, Rodriguez F (2010) The correct shale-volume characterization increases hydrocarbon reserves: case study of cretaceous formation, Lake of Maracaibo, Venezuela. In: SPE Latin American and Caribbean petroleum engineering conference. Society of petroleum engineers

4. Hilchie DW (1982) Advanced well log interpretation. Douglas W, Hilchie

5. Asquith GB, Krygowski D, Gibson CR (2004) Basic well log analysis. American Association of Petroleum Geologists, Tulsa

6. Causey GL (1991) Computer determination and comparison of volume of clay derived from petrophysical and laboratory analysis. Doctoral dissertation, Texas Tech University

7. Fisher QJ, Knipe R (1998) Fault sealing processes in siliciclastic sediments. Geol Soc (London, Special Publications) 147(1):117-134

8. Fisher QJ, Knipe RJ (2001) The permeability of faults within siliciclastic petroleum reservoirs of the North Sea and Norwegian Continental Shelf. Mar Pet Geol 18(10):1063-1081

9. Stevens SH, Moodhe KD, Kuuskraa VA (2013) China shale gas and shale oil resource evaluation and technical challenges. In: SPE Asia Pacific oil and gas conference and exhibition. Society of petroleum engineers

10. Bhuyan K, Passey QR (1994) Clay estimation from GR and neutron-density porosity logs. In: SPWLA 35th annual logging symposium. society of petrophysicists and well-log analysts

11. Ellis DV, Singer JM (2007) Well logging for earth scientists. Springer Science \& Business Media, Dordrecht

12. Worthington PF (2010) Quality-assured evaluation of effective porosity using fit-for-purpose estimates of claymineral volume fraction. J Appl Geophys 71(1):36-45

13. Yaalon DH (1961) Mineral composition of the average shale. Clay Miner 5(1):31-36

14. Hower J, Eslinger EV, Hower ME, Perry EA (1976) Mechanism of burial metamorphism of argillaceous sediment: 1. Mineralogical and chemical evidence. Geol Soc Am Bull 87(5):725-737

15. Potter PE, Maynard J, Pryor WA (2012) Sedimentology of shale: study guide and reference source. Springer Science \& Business Media, New York

16. Wang FP, Gale JF (2009) Screening criteria for shale-gas systems: Gulf Coast Association of geological societies transactions, vol 59 
17. Dargahi HJ (2013) Clay mineralogy of shale gas reservoirs through integrating infrared spectroscopy and X-ray diffraction. In: Unconventional resources technology conference (URTEC)

18. Fertl WH, Chilingarian GV, Yen TF (1982) Use of natural gamma ray spectral logging in evaluation of clay minerals. Energy Source 6(4):335-360

19. Atlas D (1982) Well logging and interpretation techniques. Dresser Industries Inc., Houston

20. Quirein JA, Gardner JS, Watson JT(1982) Combined natural gamma ray spectral/litho-density measurements applied to complex lithologies. In: SPE annual technical conference and exhibition. Society of petroleum engineers

21. Poupon A, Gaymard R (1970) The evaluation of clay content from logs. In: SPWLA 11 th annual logging symposium. Society of petrophysicists and well-log analysts

22. Larionov VV (1969) Borehole radiometry. Nedra, Moscow

23. Clavier C, Hoyle W, Meunier D (1971) Quantitative interpretation of thermal neutron decay time logs: part I. Fundamentals and techniques. J Petrol Technol 23(06):743-755

24. Steiber RG (1973) Optimization of shale volumes in open hole logs. J Petrol Technol 1973(31):147-162

25. Dewan JT (1983) Essentials of modern open-hole log interpretation. PennWell Books, Oklahoma

26. Kamel MH, Mabrouk WM (2003) Estimation of shale volume using a combination of the three porosity logs. J Petrol Sci Eng 40(3):145-157

27. Heslop A (1975) Porosity. In: Shaly-Sands. InSPWLA 16th annual logging symposium. Society of petrophysicists and well-log analysts

28. Johnson WL, Linke WA (1978) Some practical applications to improve formation evaluation of sandstones in the Mackenzie delta. In: SPWLA 19th annual logging symposium. Society of petrophysicists and well-log analysts

29. Jurado MJ, Moore JC, Goldberg D (1997) Comparative logging results in clay-rich lithologies on the Barbados ridge. Proc ODP Sci Results 156:321-334

30. Hawkins J (1992) Integration of core data for calibrated shaly-sand log analysis. In: SCA conference, paper no. 9201

31. Hesselbo SP (1996) Spectral gamma-ray logs in relation to clay mineralogy and sequence stratigraphy, Cenozoic of the Atlantic margin, offshore New-Jersey. Proc Ocean Drilling Prog Sci Results. 150:411-425

32. Schnyder J, Ruffell A, Deconinck JF, Baudin F (2006) Conjunctive use of spectral gamma-ray logs and clay mineralogy in defining late Jurassic - Early Cretaceous palaeoclimate change (Dorset, UK). Palaeogeogr Palaeoclimatol Palaeoecol 229(4):303-320

33. Serra O (2008) The well logging handbook. Editions Technip Publication, Paris

34. Cosenza P, Robinet JC, Pret D, Huret E, Fleury M, Géraud Y, Lebon P, Villiéras F, Zamora M (2014) Indirect estimation of the clay content of clay-rocks using acoustic measurements: new insights from the Montiers-sur-Saulx deep borehole (Meuse, France). Mar Pet Geol 31(53):117-132

35. Myers KJ, Bristow CS (1989) Detailed sedimentology and gamma-ray log characteristics of a Namurian deltaic succession II: gamma-ray logging. Geol Soc Lond Special Publ 41(1):81-88

36. Hurst A (1990) Natural gamma-ray spectrometry in hydrocarbon-bearing sandstones from the Norwegian Continental Shelf. Geol Soc Lond Special Publ 48(1):211-222

37. Jadoon QK, Roberts E, Blenkinsop T, Raphael AJ, Shah SA (2016) Mineralogical modelling and petrophysical parameters in Permian gas shales from the Roseneath and Murteree formations, Cooper Basin, Australia. Petroleum Explor Dev 43(2):277-284

38. Adams JA, Weaver CE (1958) Thorium-to-uranium ratios as indicators of sedimentary processes: example of concept of geochemical facies. AAPG Bull 42(2):387-430

39. Ghaderi M, Downey WS, Omrani H (2016) Geochemistry of metapelitic rocks from the Garmichay Area, East Azerbaijan, NW Iran; protolith nature and whole rock control on metamorphic mineral assemblages. Geopersia 6(1):1-18

40. Rudi AM, Afarin M (2016) Interpretation the origin and tectonic setting of coastal sediments in the Northeastern of Oman Sea. Int J Waste Resour 6(224):2

41. SLB. Schlumberger Chart Book (2009) Schlumberger educational services. France: Research and Development Section

42. Juhasz I (1981) Normalised Qv-the key to shaly sand evaluation using the Waxman-Smits equation in the absence of core data. In: SPWLA 22nd annual logging symposium. Society of petrophysicists and well-log analysts

43. Bandaru AR (2010) Clay-typing, depositional environment and framing a petrophysical model for formation evaluation in Vashista Field, Krishna-Godavari Basin—a case study. In: The 8th Biennial international conference\& exposition of petroleum geophysics, Hyderabad, India

44. Alavi M, Vaziri H, Seyed-Emami K, Lasemi Y (1997) The Triassic and associated rocks of the Nakhlak and Aghdarband areas in central and northeastern Iran as remnants of the southern Turanian active continental margin. Geol Soc Am Bull 109(12):1563-1575

45. Buryakovsky L, Aminzadeh F, Chilingarian GV (2001) Petroleum geology of the south Caspian Basin. Gulf Professional Publishing, Oxford

46. Afshar Harb A (1979) Stratigraphy, tectonic and petroleum geology of Kopet-Dagh region, northeast Iran. PhD dissertation. England, College of Science and Technology, University of London

47. Ulmishek GF (2004) Petroleum geology and resources of the Amu-Darya basin, Turkmenistan, Uzbekistan, Afghanistan, and Iran. US Department of the Interior, US Geological Survey, Iran

48. NIOC (National Iranian Oil Company, Exploration Directorate) (1986) Gonbadli geological well completion report. National Iranian Oil Company records, Tehran, Iran

49. Moussavi-Harami R, Brenner RL (1993) Diagenesis of non-marine petroleum reservoirs: the neocomian (lower cretaceous) Shurijeh Formation, Kopet-Dagh basin, NE Iran. J Petroleum Geol 16(1):55-72

50. Jozanikohan G, Norouzi GH, Sahabi F, Memarian H, Moshiri B (2015) The application of multilayer perceptron neural network in volume of clay estimation: case study of Shurijeh gas reservoir, Northeastern Iran. J Nat Gas Sci Eng 31(22):119-131

51. Moore DM, Reynolds RC (1989) X-ray diffraction and the identification and analysis of clay minerals. Oxford University Press, Oxford

52. Jozanikohan G, Sahabi F, Norouzi GH, Memarian H, Moshiri B (2016) Quantitative analysis of the clay minerals in the Shurijeh reservoir formation using combined X-ray analytical techniques. Russ Geol Geophys 57(7):1048-1063 